\title{
GAMBARAN PELAKSANAAN KONSELING KELOMPOK DENGAN TEKNIK REBT (RATIONAL EMOTIVE BEHAVIOUR THERAPY) DALAM UPAYA MENGATASI KECEMASAN MATEMATIKA SISWA SMP
}

\author{
Rahma Muti’ah \\ Program Studi Pendidikan Matematika STKIP Labuhan Batu \\ Email : rmuthea5@gmail.com
}

\begin{abstract}
Mathematical learning anxiety (anxiety mathematic) has a very important role in mathematics learning activities. This is because the anxiety felt by students influences the students' concentration ability to take part in learning activities. Besides that mathematics anxiety also influences students' ability in understanding concepts and reasoning abilities which both of these aspects greatly influence the results of a student's mathematics learning. Mathematical anxiety can be derived from the irrational belief and emotional belief and students' mastery of the basic concepts of mathematics in calculating students. To overcome the above problems, the most appropriate solution to be used is the implementation of group counseling with the REBT technique, so that expectations with students' mathematical anxiety will be low so that student learning outcomes will increase.

The method used in this study is descriptive qualitative. The population in this study were 115 students with high anxiety and low initial numeracy abilities. Consisting of 5 study groups, namely groups A, B, C, D and E, and the sample used was group A based on random results. Data collection tools used are observation and interviews, by testing the validity of the data using triangulation of sources (students, teachers and parents) and place.

From the results of the implementation it was concluded that there was a decrease in mathematics anxiety of students after participating in group counseling activities with the REBT technique. The description of the implementation of group counseling with group REBT techniques consists of 5 stages of activity, namely 1) first meeting consisting of 4 steps, namely a) initial disputing, b) identification of self-condition, c) stop irrational belief and emotional belief, d) formulate thoughts and rational feeling about mathematics, 2) second meeting, namely a) persuasive stage, b) relaxation exercise, c) home work, 3) third meeting consists of 2 steps namely a) confrontation stage, and self talk writing, 4) fourth meeting namely a) working on the task and b) facing the real situation, 5) the fifth meeting namely a) homework discussion and b) conducting an evaluation.
\end{abstract}

Keywords: REBT Counseling (Rational Emotive Behavior Theray), group, Mathematical Anxiety

\begin{abstract}
Abstrak Kecemasan belajar matematika (anxiety mathematic) memiliki peran yang sangat penting pada kegiatan pembelajaran matematika. Ini karena kecemasan yang dirasakan siswa mempengaruhi kemampuan konsentrasi siswa untuk mengikuti kegiatan pembelajaran. Selain itu kecemasan matematika juga mempengaruhi kemampuan siswa dalam pemahaman konsep dan kemampuan penalaran yang mana kedua aspek ini sangat mempengaruhi hasil belajar matematika seorang siswa. Kecemasan matematika bisa berasal dari irational belief dan emotional belief serta penguasaan siswa terhadap konsep-konsep dasar matematika siswa dalam berhitung. Untuk mengatasi permasalahan diatas maka solusi yang paling tepat digunakan adalah pelaksanaan konseling kelompok dengan teknik REBT, sehingga harapannya dengan kecemasan matematika siswa menjadi rendah maka hasil belajar siswa akan meningkat. Metode yang digunakan dalam penelitian ini adalah kualitatif deskriptif. Populasi dalam penelitian ini adalah 115 siswa dengan kecemasan tinggi dan kemampuan awal berhitung rendah. Terdiri dari 5 kelompok belajar yaitu kelompok A, B, C, D dan E, dan sampel yang digunakan adalah kelompok A berdasarkan hasil random. Alat pengumpul data yang digunakan adalah observasi dan wawancara, dengan pengujian keabsahan data dengan menggunakan triangulasi sumber (siswa, guru dan orangtua) dan tempat.
\end{abstract}


Dari hasil pelaksanaan diperoleh kesimpulan terjadi penurunan kecemasan matematika siswa setelah mengikuti kegiatan konseling kelompok dengan teknik REBT. Adapun gambaran pelaksanaan konseling kelompok dengan teknik REBT kelompok terdiri dari 5 tahap kegiatan yaitu 1) pertemuan pertama yang terdiri dari 4 langkah yaitu a) disputing awal, b) identifikasi keadaan diri, c) menghentikan irrational belief dan emotional belief, d) merumuskan pemikiran dan perasaan yang rasional tentang matematika, 2) Pertemuan kedua, yaitu a) tahap persuasif, b) latihan relaksasi, c) home work, 3) pertemuan ketiga terdiri dari 2 langkah yaitu a) tahap konfrontasi, dan menulis self talk, 4) pertemuan keempat yaitu a) mengerjakan tugas dan b) menghadapi situasi nyata, 5) pertemuan kelima yaitu a) pembahasan homework dan b) melakukan evaluasi.

Kata kunci: Konseling REBT (Rational Emotive Behaviour Theray), kelompok, Kecemasan Matematika

\section{PENDAHULUAN}

Kecemasan belajar matematika (anxiety mathematic) memiliki peran yang sangat penting pada kegiatan pembelajaran matematika. Ini karena kecemasan yang dirasakan siswa mempengaruhi kemampuan konsentrasi siswa untuk mengikuti kegiatan pembelajaran. Selain itu kecemasan matematika juga mempengaruhi kemampuan siswa dalam pemahaman konsep dan kemampuan penalaran yang mana kedua aspek ini sangat mempengaruhi hasil belajar matematika seorang siswa. Kecemasan matematika bisa berasal dari irational belief dan emotional belief serta penguasaan siswa terhadap konsep-konsep dasar matematika.

Umumnya siswa yang mengalami hasil belajar rendah memiliki kecemasan belajar matematika yang tinggi. Dari hasil wawancara dengan siswa yang memiliki kecemasan belajar matematika tinggi, penyebab utama mereka mengalami rasa cemas karena mereka berpikir bahwa mereka tidak akan mampu mengerjakanmatematika bagaimanapun usaha mereka. Semakin mereka berusaha untuk menjawab pertanyaan guru atau soal yang diberikan mereka semakin merasakan pusing, mual dan berkeringat. Sehingga ketika menghadapi soal mereka lebih memilih untuk melihat pekerjaan teman, atau bahkan tidak mengerjakan soal tersebut sama sekali dan mempersiapkan diri untuk menerima hukuman atau sanksi dari guru.

Mereka berpikir bahwa bagaimanapun belajar matematika mereka adalah orang-orang yang memang "bodoh" dalam matematika dan bagaimanapun mereka berusaha mereka tidak akan bisa mempelajari atau memahami matematika dan hanya orang-orang yang memang pintar yang mampu untuk mengerjakan matematika. Selain itu mereka juga merasa bahwa soal-soal matematika sangat sulit untuk dipahami. Ada juga siswa yang mengeluhkan kesulitan memahami matematika karena dia menilai guru matematika mereka sangat "garang" (suka marah-marah dan serius ketika mengajar) yang membuat suasana kelas menjadi sangat tegang dan ini membuat dirinya sulit untuk berkonsentrasi mendengarkan penjelasan dari guru. Siswa lain mengatakan bahwa tidak jarang guru hanya memberikan soal lalu meminta siswa untuk menyelesaikannya tanpa terlebih dahulu guru menjelaskan bagaimana cara mengerjakannya, siswa diminta untuk belajar mandiri dengan melihat contoh yang ada di buku pegangan.

Untuk mengcrosscek hasil wawancara dengan siswa, maka peneliti melakukan observasi dengan melihat langsung bagaimana cara guru matematika mengajar di kelas. Pada umumnya cara guru mengajar dikelas adalah dengan cara menuliskan dan menjelaskan contoh soal, lalu memberi kesempatan kepada siswa untuk bertanya, ketika siswa tidak ada yang bertanya maka guru langsung memberikan soal untuk dikerjakan siswa, kemudian guru meninggalkan siswa di kelas dan berpesan untuk mengantar lembar jawaban siswa ke ruang guru. Kondisi siswa ada yang terlihat tegang dan ada juga yang hanya bersikap apatis tidak peduli dan sibuk mengerjakan hal lain. Ketika guru pergi para siswa mengerjakan soal dengan meminta atau 
menyalin pekerjaan teman mereka yang mereka rasa adalah orang yang paham dengan soal tersebut.

Di bidang pendidikan masalah hasil belajar siswa yang rendah menjadi fokus perhatian, dan masalah ini banyak faktor yang mempengaruhinya, seperti kondisi siswa, media pembelajaran, metode pembelajaran yang digunakan guru, gaya/metode belajar dan lain-lain. Berbagai cara sudah dilakukan sekolah untuk mengatasi hasil belajar matematika siswa yang rendah seperti memberikan les tambahan, melakukan remedial, guru mengikuti pelatihan kegiatan pembelajaran dan bahkan mengikuti kegiatan yang dilakukan oleh Ganesha penerbit tentang konseling kecemasan siswa menghadapi Ujian Nasional. Namun belum terlihat adanya perubahan yang signifikan, untuk itu dalam kegiatan pengabdian ini berusaha untuk membantu mitra (pihak sekolah) untuk meningkatkan hasil belajar matematika siswa dengan menggunakan teknik terapi REBT danmetode mengajar dengan pendekatan matematika realistik(PMR).

Alasan penggunaan terapi REBT dan metode PMR adalah hasil belajar siswa yang rendah umumnya disebabkan karena siswa mengalami kecemasan matematika. Kecemasan matematika siswa muncul akibat dari irational belief, emotional belief dan tingkat penguasaan konsep-konsep dasar matematika. untuk itu solusi yang paling tepat digunakan untuk mengatasi kecemasan matematika siswa adalah dengan menggunakan terapi REBT untuk mengubah irational belief dan emotional belief dan metode pembelajaran PMR untuk meningkatkan penguasaan konsep-konsep dasar matematika siswa. Ini dilakukan karena siswa yang kurang menguasai konsep-konsep dasar dalam ilmu matematika akan mengalami kesulitan untuk melakukan penalaran maupun analisa soal-soal yang diberikan guru. Kondisi ini yang menambah tingkat kecemasan matematika siswa. Diharapkan jika siswa tidak lagi mengalami kecemasan matematika maka akan dapat meningkatkan hasil belajar siswa nantinya.

\section{METODE}

Metode yang digunakan dalam penelitian ini adalah kualitatif deskriptif. Populasi dalam penelitian ini adalah 115 siswa dengan kecemasan tinggi dan kemampuan awal berhitung rendah. Terdiri dari 5 kelompok belajar yaitu kelompok A, B, C, D dan E, dan sampel yang digunakan adalah kelompok A berdasarkan hasil random. Alat pengumpul data yang digunakan adalah observasi dan wawancara, dengan pengujian keabsahan data dengan menggunakan triangulasi sumber (siswa, guru dan orangtua) dan tempat.

\section{HASIL \& PEMBAHASAN}

Pelaksanaan dari kegiatan konseling REBT dalam upaya mengatasi tingkat kecemasan matematika siswa di SMP terlihat pada gambaran sesitiap pertemuan yang digambarkan dibawah ini:

Gambaran Konseling Rational Emotive Behaviour Therapy (REBT) untuk menurunkan tingkat
kecemasan matematika (mathematic anxiety)




\begin{tabular}{|c|c|}
\hline Menit) & $\begin{array}{l}\text { adalah salah } \\
\text { 2) Latihan relaksasi ketika kecemasan matematika muncul } \\
\text { 3) Home work (untuk mencoba teknik relaksasi ketika mengalami } \\
\text { kecemasan dalam pelajaran matematika di sekolah) }\end{array}$ \\
\hline $\begin{array}{l}\text { Pertemuan } \\
\text { III } \quad(30 \\
\text { Menit })\end{array}$ & $\begin{array}{l}\text { 1) Tahap konfrontasi : memeriksa hasil home work siswa dan } \\
\text { mengkonfrontasi hasil pemikiran siswa yang masih memiliki irrational } \\
\text { belief dan emotional belief } \\
\text { 2) Meminta siswa untuk menuliskan kembali di lembar self talk }\end{array}$ \\
\hline $\begin{array}{l}\text { Pertemuan } \\
\text { IV } \quad(30 \\
\text { Menit })\end{array}$ & $\begin{array}{l}\text { 1) Menyusun tugas-tugas yang harus dilakukan siswa ketika mengikuti } \\
\text { pelajaran matematika dengan menggunakan pendekatan PMR } \\
\text { 2) Mengingatkan siswa untuk mengikuti pembelajaran PMR dan } \\
\text { menerapkan apa-apa yang sudah dipelajari di setiap sesi konseling. }\end{array}$ \\
\hline $\begin{array}{l}\text { Pertemuan } \\
V(60 \text { menit })\end{array}$ & $\begin{array}{l}\text { Membahas homework (tugas-tugas) yang sudah diberikan } \\
\text { Melakukan evaluasi kemajuan yang dirasakan oleh siswa selama } \\
\text { mengikuti kegiatan konseling }\end{array}$ \\
\hline
\end{tabular}

Pelaksanaan kegiatan REBT dilakukan berdasarkan tahapan-tahapan pelaksanaan kegiatan yang telah disusun, adapun hasil pelaksanaan kegiatan akan dijabarkan dibawah ini:

\section{Pertemuan I}

Pada tahap ini pertama kali dilakukan dengan menjelaskan tentang apa yang dimaksud dengan kecemasan matematika, ciriciri kecemasan, faktor-faktor yang mempengaruhi kecemasan serta contoh-contoh pengaruh kecemasan matematika tehadap perilaku seseorang. Kemudian setelah itu melakukan disputing awal tentang kecemasan matematika dengan mengatakan kepada siswa tentang bahayanya untuk memiliki pemikiran irational belief dan emotional belief. Selain itu juga meminta siswa untuk melihat dari sisi lain tentang peristiwa-peristiwa yang membuat siswa merasa cemas. Konselor juga memberikan beberapa contoh-contoh tentang bagaimana kecemasan mempengaruhi perilaku seseorang. Siswa terlihat antusias dan mendengarkan selama proses konseling dilakukan ini terlihat dari siswa yang diam dan menjawab ketika diberi pertanyaan oleh konselor. Hanya saja ketika ditanya tentang pelajaran apa yang tidak disukai hampir seluruh siswa mengatakan matematika, ketika ditanya tentang kenapa matematika yang tidak disukai umumnya mengatakan karena pelajaran matematika sangat sulit dipahami, banyak rumus yang harus dihapal, guru nya pemarah, susah mengerjakannya, banyak jalan yang harus dilakukan untuk cari hasil, susah perkalian, susah pembagian dan lain-lain.
Langkah berikutnya adalah dengan melakukan identifikasi diri (self awareness) dengan memberikan lembaran tentang kondisikondisi yang pernah dialami siswa ketika di sekolah menyebabkan munculnya kecemasan matematika. Kemudian bersama-sama dibahas untuk kegiatan berikutnya yaitu merumuskan pemikiran dan perasaan yang lebih rasional tentang matematika berdasarkan lembaranlembaran kondisi-kondisi yang menyebabkan munculnya kecemasan matematika. Adapun kondisi-kondisi yang muncul berdasarkan irational dan emotional belief yaitu (1) matematika adalah pelajaran yang sulit dan membosankan, (2) pelajaran yang membutuhkan hapalan rumus-rumus matematika, (3) memiliki rumus dan langkahlangkah pengerjaan/penyelesaian yang rumit dan susah untuk dipahami, (4) pelajaran yang menyiksa dan sulit untuk dipahami terutama pada saat mengerjakan tugas, (5) selalu ada soal-soal dan tugas-tugas yang harus dikerjakan, (6) guru matematika kejam dan suka marah, (7) saya anak yang malas dan bodoh dalam matematika.

\section{Pertemuan II}

Pada tahap ini yang dilakukan adalah persuasive dan latihan relaksasi.Tahap persuasive adalah dengan memberikan contohcontoh pemikiran yang irasional dan meminta siswa untuk mencari pembanding disaat siswa mengalami hal yang berbeda. Misalkan ketika siswa mengatakan pelajaran matematika sulit, konselor menanyakan pernah tidak kamu dapat mengerjakan soal matematika, ketika siswa 
menjawab iya, konselor menanyakan kenapa kamu bisa mengerjakannya, apa yang kamu lakukan hingga kamu bisa mengerjakannya, siswa menjawab karena dia mendengarkan dengan sungguh-sungguh dan sudah latihan soal tersebut. Namun tetap ada juga siswa yang tetap mengatakan bahwa matematika memang sulit dan tidak menyenangkan. Tahap persuasif ini berulang kali dilakukan menyesuaikan dengan cara berpikir mereka yang irasional dan menggantinya dengan yang rasional. Kemudian konselor menjelaskan bahwa ketika kita merasa senang dan memandang positif suatu pekerjaan maka kita akan dengan mudah mengerjakannya lalu konselor memberikan contohnya.

Latihan relaksasi dilakukan dengan memberikan teknik relaksasi yaitu 1) menghilangkan pikiran-pikiran dan perasaanperasaan yang irasional dan menggantinya dengan rasional, 2) menarik napas dalamdalam, dan 3) melakukan self talk yaitu meyakinkan diri bahwa dirinya bisa melakukan apa yang diatakutkan (saya bisa, saya mampu dll). Pada saat latihan relaksasi konselor menanyakan apa yang dirasakan siswa, siswa mengatakan lebih tenang, namun ada beberapa siswa yang sambil bermain-main melakukan tarik napas dalam-dalam.

\section{Pertemuan III}

Pada tahap ini siswa diminta untuk menulis apa yang mereka rasakan dan pikirkan tentang matematika kemudian membuat apa yang seharusnya dilakukan ketika pikiran dan emosi yang tidak rasional tersebut muncul. Waktu pengerjaan adalah 30 menit dan 30 menit kemudian konselor dan siswa membahas satu persatu tentang pemikiran dan perasaan yang irasional. Dari hasil terlihat siswa umumnya memiliki cara berpikir dan memiliki perasaan irrasional yang hampir sama. Selama tahap ini konselor membacakan pikiran dan perasaan yang irrasional, kemudian menanyakan kembali kesiswa pikiran dan perasaan rasional apa yang seharusnya dilakukan. Secara keseluruhan siswa dapat menjawab contoh-contoh pemikiran dan perasaan yang lebih rasional, hanya saja siswa mengatakan ketika mempraktekkan dalam kehidupan sehari-hari masih sulit namun mereka mengatakan akan berupaya untuk mencoba melakukannya.
Umumnya mereka memandang bahwa 1) matematika adalah pelajaran yang sulit karena banyak rumus yang harus dihapal, 2) banyak jalan atau langkah yang harus dikerjakan, 3) menakutkan, 4) pusing setiap melihat angkaangka, 5) takut salah ketika mengerjakan ke papan tulis nanti ditertawakan teman-temannya dan lain-lain. Untuk mengkonfrontasi hasil pemikiran siswa dengan membandingkan ketakutan mereka terhadap matematika dengan kesukaan mereka terhadap mata pelajaran tertentu.

Diakhir kegiatan konselor meminta siswa untuk berjanji melakukan teknik-teknik yang harus dilakukan oleh siswa ketika kecemasan matematika muncul yaitu 1) menghilangkan pikiran-pikiran dan perasaan-perasaan yang irasional dan menggantinya dengan rasional, 2) melakukan teknik relaksasi yaitu menarik napas dalam-dalam, dan 3) melakukan self talk yaitu meyakinkan diri bahwa dirinya bisa melakukan apa yang dia takutkan.

\section{Pertemuan IV}

Pada tahap ini siswa diberikan tugas untuk mengikuti kegiatan pembelajaran dengan pendekatan PMR, dimana pada saat pelaksanaan kegiatan pembelajaran PMR melakukan tugas yaitu untuk berusaha maju kedepan kelas ketika diminta guru kedepan, berusaha untuk melakukan teknik relaksasi ketika merasakan ciri-ciri cemas, selalu berupaya menghilangkan pikiran dan emosi yang irrasional dan mengganti dengan yang rasional. Tugas-tugas yang diberikan dalam bentuk lembaran tugas yang berisikan tentang kondisi yang terjadi yang memunculkan kecemasan matematika dan langkah-langkah apa yang dilakukan siswa untuk mengatasi masalah tersebut. Kemudian meminta siswa untuk kesediaan mengikuti pembelajaran dengan pendekatan PMR sebagai upaya untuk membantu siswa menghadapi kondisi nyata dalam pembelajaran matematika.

Selama pelaksanaan kegiatan pembelajaran PMR konselor selalu mengawasi siswa. Siswa yang terlihat memiliki kecemasan akan didekati secara personal dengan meminta siswa untuk melawan rasa cemasnya dan mencoba untuk lebih tenang, seperti ketika disuruh guru PMR untuk menulis jawaban di papan tulis, namun siswa terlihat tidak mau dan ketika dipegang tangan siswa langsung dingin, 
maka konselor langsung melakukan persuasif dengan mempengaruhi cara berpikir siswa untuk mau mencoba dan berani maju ke depan mengerjakan soal yang diberikan guru. Begitu seterusnya konselor akan tetap mendampingi siswa selama kegiatan pembelajaran matematika dengan PMR berlangsung. Di SMP Negeri 1 NA IX X umumnya terlihat langsung dapat menerapkan teknik-teknik relaksasi dan tugas-tugas yang diberikan konselor ini terlihat mereka selalu mengingat apa yang ditugaskan pada mereka ketika konselor mengingatkan. Ketika pembelajaran siswa juga sudah terlihat antusias ketika mengikuti pembelajaran, hanya saja ada di rombongan belajar B yang memang memiliki tingkat kecemasan sangat tinggi, hingga masih juga belum bisa menerapkan hasil pelaksanaan REBT ini terlihat ketika di kertas jawaban siswa dapat mengerjakan namun ketika diminta ke depan mengerjakan di papan tulis siswa tidak mau dan hanya menundukkan kepala. Bahkan terkadang dia hanya diam ketika diberikan pertanyaan rebutan.

Di kelas SMP Negeri 2 NA IX X ketika pembelajaran PMR berlangsung ada anak yang memiliki kecemasan tinggi ketika diminta untuk memberikan jawaban tersebut siswa terlihat cemas dan tidak bisa menjawab lalu konselor meminta siswa untuk melakukan teknik relaksasi dan hasilnya siswa mampu menjawab soal yang diberikan.

\section{Pertemuan V}

Pada tahap ini siswa diminta untuk membacakan home work yang telah dikerjakan oleh siswa kemudian bersama-sama membahas apakah yang sudah dilakukan sudah rasional. Konselor mengajak seluruh siswa untuk samasama membahas setiap perilaku yang dimunculkan apakah sudah rasinal atau tidak, jika belum rasional konselor mengajak siswa lain untuk memberikan pendapat perilaku apa yang sebaiknya dilakukan untuk mengatasi setiap kondisi-kondisi yang dialamisiswa.

Setelah setiap home work siswa sudah dibahas, kemudian konselor mengajak siswa untuk melakukan evaluasi kemajuan. Pelaksanaan evaluasi kemajuan dengan cara bertanya kepada masing-masing siswa tentang peruahan apa yang dirasakan siswa setelah mengikuti kegiatan konseling dengan teknik REBT kelompok.
Dari hasil evaluasi umumnya masih banyak siswa yang mengalami kecemasan walaupun intensitasnya menurun. Hanya saja siswa sudah mulai mengenal dan mendeteksi ketika kecemasan matematika tersebut datang dan mereka sudah melakukan upaya untuk mengurangi tingkat kecemasan mereka dengan cara menarik nafas dalam-dalam, menghembuskan secara perlahan, kemudian mempengaruhi pemikiran negatif yang muncul serta melakukan self talk agar dirinya tenang dan mampu mengikuti pembelajaran kembali. Umumnya kecemasan matematika yang tinggi muncul ketika diminta guru untuk mengerjakan tugas dipapan tulis, menjelaskan jawaban, ketika nama disebutkan oleh guru dan mengikuti ujian atau ulangan matematika.

Hanya saja masih ada siswa yang malas mengikuti sesi terapi karena menurut dirinya matematika memang susah untuk dikerjakan bagaimanapun kita mempengaruhi pikiran untuk tidak takut matematika. Umumnya kondisi yang membuat munculnya kecemasan matematika adalah pada saat guru memanggil nama dan meminta untuk mengerjakan soal di depan papan tulis, mengerjakan soal-soal ulangan dengan memiliki batas waktu. Selain itu kondisi dimana siswa tinggal sedikit yang belum selesai mengerjakan dan teman-teman yang lain sudah hampir selesai mengerjakan soal ulangan. Kondisi kemampuan awal matematika siswa dalam berhitung yang masih sangat rendah juga menyulitkan konselor dan guru untuk meningkatkan kemampuan siswa, ditambah lagi kompetensi kemampuan awal matematika siswa yang heterogen juga menjadi kendala dalam pelaksanaan kegiatan pengadian ini.

Pelaksanaan evaluasi dan monitoring dilakukan lebih kurang 2 minggu setelah pelaksanaan tes akhir dilakukan yaitu dengan menanyakan kembali ke siswa dan guru mengenai manfaat dan perubahan yang dirasakan setelah mengikuti kegiatan pelaksanaan pengabdian yang telah dilakukan. Adapun penjabaran pelaksanaan evaluasi dan monitoring akan dijelaskan dibawah ini:

Pada saat evaluasi diketahui baik dari guru maupun siswa mengaku bahwa telah terjadi peningkatan dalam pembelajaran karena umumnya siswa yang mengikuti kegiatan pengabdian adalah siswa-siswa yang sebenarnya berprestasi di sekolah pada hari-hari 
biasa hanya saja pada saat pelaksanaan tes awal umumnya siswa merasa cemas dan tegang karena jenis soal yang diberikan umumnya adalah soal cerita yang hasilnya umumnya menuntut siswa untuk melakukan komunikasi matematika. Hanya saja masih ada beberapa siswa yang memang kemampuan matematika masih sangat rendah seperti tidak hafal perkalian dan pembagian bilangan sederhana memang terlihat masih cenderung rendah dalam kemampuan awal matematika dalam berhitung walaupun ada yang mengalami peningkatan namun hasil peningkatan tidak terlalu signifkan, bahkan ada siswa yag justru stag dan tidak mengalami peningkatan dalam hasil pembelajaran mereka sehari-hari. Siswa juga tetap menerapkan langkah-langkah yang akan dilakukan ketika merasakan kecemasan. Umumnya kecemasan yang muncul pada saat maju ke depan kelas, menjawab pertanyaan dari guru dan saat ulangan maupun ujian matematika.

Dari pihak guru dan konselor (guru BK) yang mengikuti kegiatan pelatihan tentang teknik REBT dan PMR mengatakan bahwa guru BK menerapkan prinsip-prinsip pelaksanaan konseling REBT selain untuk mengatasi permasalahan siswa yang memiliki nilai skor matematika yang rendah juga menerapkan prinsip-prinsip tersebut dalam mengatasi permasalahan-permasalahan perilaku anak di sekolah. Sedangkan guru bidang studi pelajaran matematika menganggap terkadang dia belum sepenuhnya menerapakan metode PMR dalam mengajar ini dikarenakan dirinya masih mengalami kesulitan untuk mengaktifkan siswa dalam kegiatan-kegiatan atau tahap-tahap dalam pendekatan PMR. Hanya saja guru bidang studi pelajaran matematika mengakui bahwa dengan meningkatkan kemampuan awal matematika siswa dalam berhitung membantu siswa lebih mudah memahami pelajaranpelajaran yang diajarkan berikutnya. Di dalam kelas juga terlihat adanya perubahan siswa dalam belajar matematika yang biasanya wajahwajah terkesan tegang dan cemas, atau bahkan wajah-wajah yang apatis. Hanya saja pada saat ini siswa bisa lebih tenang dalam belajar dan mengikuti pembelajaran denga baik.

Pihak sekolah juga memiliki rencana untuk melakukan les tambahan untuk tetap berupaya meningkatkan kompetensi kemampuan awal matematika siswa, agar siswa lebih siap untuk mengikuti pembelajaran matematika selanjutnya. Selain itu ppihak sekolah juga meminta untuk melakukan kegiatan penelitian dan pengadian kembali di sekolah mereka, agar sekolah mereka terus dapat meningkat kualitasnya.

\section{SIMPULAN}

Berdasarkan hasil penerapan konseling kelompok dengan teknik REBT kelompok diatas diketahui bahwa dalam pelaksanaan konseling kelompok dengan teknik REBT dilakukan dengan menggunakan 5 tahap pertemua yang pada tiap pertemuan memiliki langkah-langkah.

Selain itu penerapan konseling kelompok dengan teknik REBT ini dapat digunakan dalam upaya mengatasi kecemasan matematika dan perilaku-perilaku lain yang bersumber dari irrational belief dan emotional belief siwa. Dalam upaya mengatasi kecemasan matematika siswa dalam langkah mengikuti pembelajaran matematika di dunia nyata sebaiknya dengan menggunakan pembelajaran dengan pendekatan matematika realistik (PMR), ini karena PMR mampu meningkatkan kemampuan siswa dan menciptakan suasana pembelajaran yang menyenangkan.

\section{DAFTAR RUJUKAN}

Anita, Ika Wahyu. 2014. Pengaruh Kecemasan Matematika (Mathematics Anxiety) Terhadap Kemampuan Koneksi Matematis Siswa SMP. Jurnal. Infinity Jurnal Ilmiah Program Studi Pendidikan Matematika STKIP Siliwangi Bandung, Vol. 3 No.1 Februari2014.

Ekawati, Aminah. 2015. Pengaruh Kecemasan Terhadap Hasil Belajar Matematika Siswa Kelas VII SMP Negeri 13 Banjarmasin. Jurnal. Math Didactic: Jurnal Pendidikan Matematika. ISSN 2442-3041. Vol. 1 No. 3 September-Desember 2015.

Ellis, Albert. 2006. Rational Emotive Behavioral Approaches to Childhood Disorders. Theory, Practice and Research. USA : Springer 
Hariyanti, Desi Dwi. 2013. Penerapan Konseling Kelompok Rational Emotive Behaviour Untuk Meningkatkakn Motivasi Belajar Siswa Kelas VIII G SMP Yayasan Pendidikan 17 Surabaya. Jurnal. Jurnal BK UNESA, Volume 01 Nomor 01 Tahun 2013, $0-216$.

Irmayanti. 2013. Peningkatan Kemampuan Pemecahan Masalah dan Self Efficacy Matematis Siswa SD Melalui Pendekatan Matematika Realistik. Thesis tidak diterbitkan. Medan : Sekolah Pascasarjana Universitas Negeri Medan.

Munasiah. 2015. Pengaruh Kecemasan Belajar dan Pemahaman Konsep Matematika Siswa Terhadap Kemampuan Penalaran Matematika. Jurnal. Jurnal formatif 5 (3) : 220-232, 2015 ISSN : 2088-351X.

Muti'ah, Rahma. 2014. Pengaruh Kecerdasan Emosional Siswa Terhadap Kecemasan Belajar Matematika. Jurnal. Jurnal Eduscience ISSN 2303- 355x Vol.2 No. 1 Oktober 2014 Hal; 32-43.

Muhlisin, N. Dantes dan Sariyasa. 2013. Pengaruh Pendekatan Pembelajaran Matematika Realistik Terhadap Hasil Belajar Matematika Ditinjau dari Tingkat Kecemasan Belajar Siswa. Jurnal. E-journal program pascasarjana Universitas Pendidikan Ganesha Vol. 3 tahun 2013.

Wicaksono, Arief Budi dan M. Saufi. 2013. Mengelola Kecemasan Siswa Dalam Pembelajaran Matematika. Prosiding. ISBN : 978-979-16353-9-4. 